This article was downloaded by: [New York University]

On: 19 May 2015, At: 16:32

Publisher: Routledge

Informa Ltd Registered in England and Wales Registered Number: 1072954

Registered office: Mortimer House, 37-41 Mortimer Street, London W1T

3J H, UK

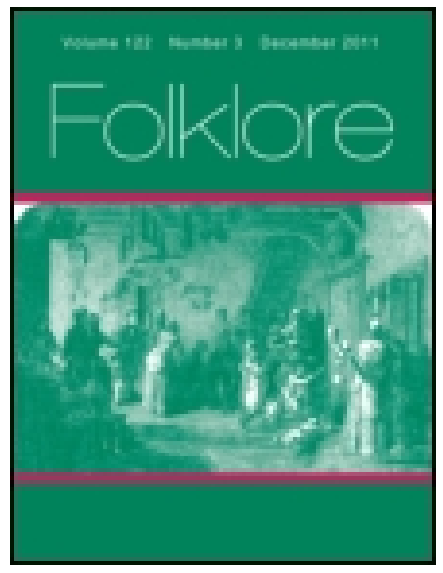

\title{
Folklore
}

Publication details, including instructions for authors and subscription information:

http:// www. tandfonline.com/loi/ rfol20

\section{The Sun-God's Axe and Thor's Hammer}

\author{
Oscar Montelius ${ }^{a}$ \\ a Royal Antiquary, Stockholm \\ Published online: 14 Feb 2012.
}

To cite this article: Oscar Montelius (1910) The Sun-God's Axe and Thor's Hammer, Folklore, 21:1, 60-78, DOI: 10.1080/0015587X.1910.9719915

To link to this article: http:// dx. doi. org/ 10.1080/0015587X.1910.9719915

\section{PLEASE SCROLL DOWN FOR ARTICLE}

Taylor \& Francis makes every effort to ensure the accuracy of all the information (the "Content") contained in the publications on our platform. However, Taylor \& Francis, our agents, and our licensors make no representations or warranties whatsoever as to the accuracy, completeness, or suitability for any purpose of the Content. Any opinions and views expressed in this publication are the opinions and views of the authors, and are not the views of or endorsed by Taylor \& Francis. The accuracy of the Content should not be relied upon and should be independently verified with primary sources of information. Taylor and Francis shall not be liable for any losses, actions, claims, proceedings, demands, costs, expenses, damages, and other liabilities whatsoever or howsoever caused arising directly or indirectly in connection with, in relation to or arising out of the use of the Content.

This article may be used for research, teaching, and private study purposes. Any substantial or systematic reproduction, redistribution, reselling, loan, sub-licensing, systematic supply, or distribution in any form to anyone is 
expressly forbidden. Terms $\&$ Conditions of access and use can be found at http://www.tandfonline.com/page/terms-and-conditions 


\section{THE SUN-GOD'S AXE AND THOR'S HAMMER.}

BY OSCAR MONTELIUS, ROYAL ANTIQUARY, STOCKHOIM.

ANYONE seeking in the cottages of Sweden of to-day for stone implements, ought to ask whether any thunderbolts or Thor-bolts (Thorsviggar) have been found, rather than to enquire for stone axes (Stenyxor). The former term implies just what is wanted, while the cottagers generally imagine that stone axes are axes used for working stone.

In the different countries of Europe, and in other parts of the world, such as Brazil and Japan, there is a current belief amongst the people that the stone axes which are found in the ground, and the use of which is forgotten, are thunderbolts, weapons by means of which the god of thunder kills his enemies, when it looks as if they had been struck by lightning. Only three years ago a man in the northern part of Sweden dug a hole in the ground where he hoped to find a thunderbolt; there had just been a lightning stroke in this place.

On looking backwards we find that in ancient times there was a widespread belief in Greece, more than 2000 years ago, that stone axes had the character of thunderbolts. But we also find,--and this is closely connected with what has been said above,-that the axe has from time immemorial been considered, both in Greece and elsewhere, a symbol of the thunder or sun god. It soon becomes evident that the god of the sun and the god of thunder have originally been one and the same deity, although the ancients had not learnt to understand as we 
have the intimate connection which exists between the thunder and the sun.

Amongst the Aryan peoples of India we find a god whose favourite weapon in his fight against the demons is the thunderbolt. This god, glorified above all others in the Rigveda hymns, was Indra, that fabulously strong deity who corresponds to the Thor of the Scandinavians. His original weapon was the "heavenly stone" which the primeval smiths had sharpened for him; it was thus a kind of stone axe. Then a bolt was prepared for him which, according to some hymns, was made out of the skull of a horse, while others describe it as being made of bronze. Strictly speaking, it was made of "ayas," the same word as the Latin "aes," which word in the earlier Indian language signifies copper or bronze, but which in later times, after iron became known, means this new metal.

From the fact that one of the Rigveda hymus gives to the lightning the name of the axe of heaven, we may rightly infer that Indra's axe is really the lightning.

The Indian myths relate how a cunning being forfeited his head to the artist who forged the bolt for Indra, but saved it by stratagem. The northern myths tell the same legend about Loke and the gnome who forged the hammer for Thor. The earth is the mother of Thor as well as of Indra. Indra drives about, just as Thor does, in a chariot, the wheels of which roll through the air. We have good reason to believe that, according to the earliest notions, Indra's chariot, like that of Thor, was drawn by bucks. A later belief was that it was drawn by horses, but these horses could coine to life again, exactly as Thor's bucks did, after having been killed and eaten.

We also come across gods carrying axes in their hands in several parts of Western Asia.

One of the bas-reliefs dug up from the ruins of the Assyrian Nimrud represents a procession in which several images of gods are carried in exactly the same manner 


\section{The Sun-God's Axe and Thor's Hammer.}

as the images of saints in Roman Catholic processions. One of these god-images from Nineveh (Fig. I) holds in his right hand an axe, and in his left a thunderbolt. It would perhaps have been difficult to say with certainty that this implement, three pronged at both ends, represents the lightning, had not its shape lived on in Greek art almost unaltered.

The axe that the Assyrian god carries in his hand has but one edge. The axes of other gods from Western Asia are, as a rule, edged on both sides (Fig. 2, Hittite).

Not far from Mylasa in Caria there was a place named Labranda, where a God was worshipped whom the Greeks called Zeus Labrandeus or Zcus Stratios. He is shown on coins from Mylasa as carrying in his hand a double axe, an axe edged on both sides. We also find him represented with javelin and eagle, both usual attributes of the sun god. The fact that the god on some coins is represented with lightning and javelin, whereas he generally carries axe and javelin, is a still further proof of the close connection between the axe and lightning. A wooden image is known of this god carrying a double axe in his right hand and a javelin in his left. The handles of both axe and javelin were so long that they reached the ground.

In some of the east-Mediterranean countries, a word labrys signifies axe, and Plutarch has connected this word with the name of the god. It was suggested by Mr. Max Mayer that the well-known Labyrinthos of Knossos was derived from that name Labrayndos or Labrynthios. Some years after this suggestion had been published, Dr. Arthur Evans found that in the royal palace of Knossos, evidently identical with the Labyrinthos, the double axe, the labrys, had been worshipped. The holy figure of the double axe was found everywhere in this old building (Irig. 3).

Because the double axe was a religious symbol, it was 
Plate I.

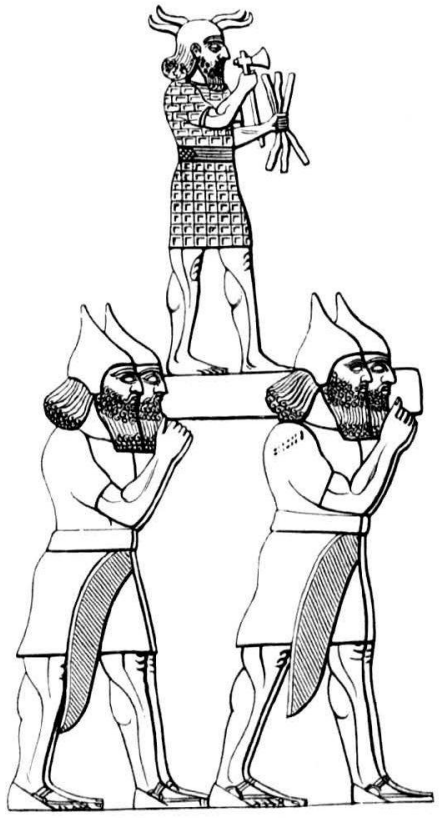

Fig. 1.

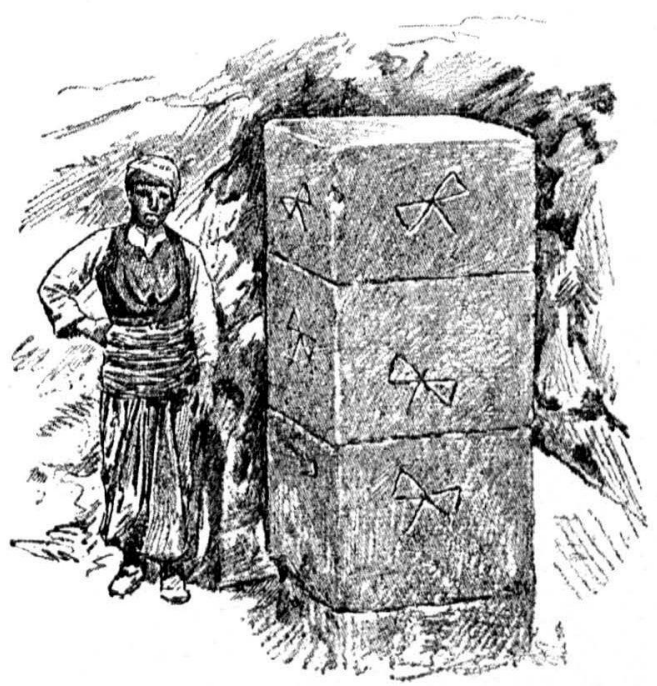

Fig. 3.

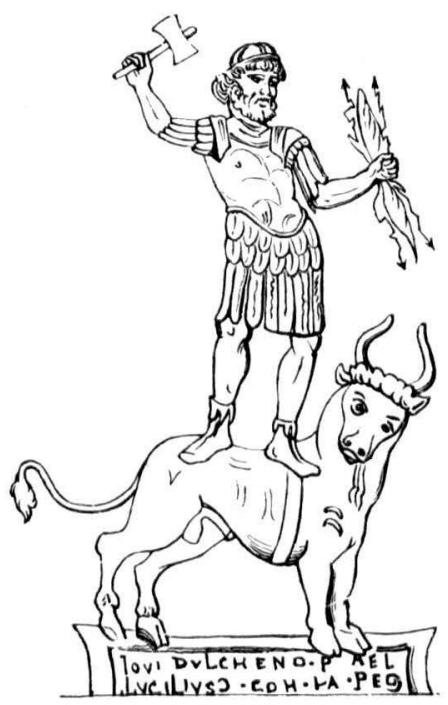

Fig. 5.

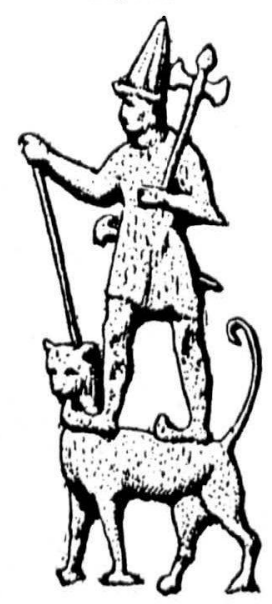

Fig. 2.

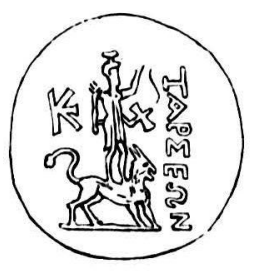

Fig. 4.

THE SUN-GOD'S AXE AND THOR'S HAMMER.

To face $p .62$. 
used as an architectural ornament in Asia Minor as well as in Crete.

We find a god with a double axe not only in Labranda, but also in other towns of Asia Minor and Syria, as, for instance, in Tarsos. Coins from that town (Fig. 4) show us the god holding in his hand an axe of this description. Like many other Syrian gods (e.g. Fig. 2) he is represented as standing on an animal, in this case a lion. A Greek author alludes to a curious ceremony in which this god played the principal part. The image of the god was burnt on a huge pyre, in view of an immense crowd of spectators. In the first century of our era, when this author was living, the ceremony took place only every five years. Judging from what is known about similar ceremonies in other places, we may presume that in earlier times the god was burnt every year, and that, when the fire had burnt down, the birth of a new god was celebrated. It is the god of the sun that is thus celebrated. $\mathrm{He}$ it is that dies every year in order yearly to rise again. The season of the festival in Tarsos is not known, but it was probably at the vernal equinox, that critical time in the yearly life of the sun when the power of the sun is again manifesting itself on the earth. At that time the Christian Church still celebrates the festival of the Resurrection.

In Roman times there was a well-known Syrian god with a double axe, whom the Romans called Jupiter Dolichenus, after the town of Doliche, the present Doluc in Commagene, that part of Syria which lies between the ordinary crossing-place of the Euphrates and Mount Amanus. The god was probably called Baal by the town's own inhabitants. Like the god in Tarsos he is represented as standing on an animal, in this case a bull. In his right hand he holds a double axe, and in his left the lightning (Fig. 5).

About the middle of the second century after Christ, Syrian gods, and amongst others Jupiter Dolichenus, became known and worshipped in different parts of the 


\section{The Sun-God's Axe and Thor's Hammer.}

Roman Empire. Jupiter Dolichenus had one temple on the Aventine and another on the Esquiline in Rome in the time of the later limperors. Moreover, inscriptions were dedicated to him in all the frontier provinces of the Empire, - in Dacia and Pannonia, in Germania and Britain. $\mathrm{He}$ was worshipped chiefly by soldiers, but also by merchants and other Syrian immigrants.

Very early the double axe was considered as a symbol, also, on the islands west of Asia Minor and in Greece. Of the Cretan labry's I have already spoken. Whenever it is possible to asccrtain of what god it is the symbol, it is always found to be of the sun grod.

An old relief has been discovered at Kameiros in Rhodes. Amongst its firures there is a man holding a double axe with a short handle in one hand, and a thunderbolt in the other (Fig. 6). The relief is damaged, so that the man's head and the top part of the thunderbolt cannot now be seen.

In Crete, and in other islands of the Erraean Sea, double axes of bronze have been found, the votive character of which is obvious, as their blades are always too thin, and grencrally also too small, to have been of any real use.

Duringr the excavations at Olympia a number of such votive double axes of thin bronze have been discovered in the deepest layers of the precinct dedicated to the sun god from time out of mind (Figs. 7 and 8 ).

Small double axes of thin gold date from a still carlier period, from the second millennium B.C. They have been found in the maynificent royal tombs of the Mycenatan acropolis. It is quite evident that they are votive axes, which is further confirmed by the fact that some of them are fixed between the horns of small bull's heads, made of thin gold (Fig. 9). A large bull's head, from one of the Mycenzean tombs, has between the horns on its forchead a big sun-like flower. We know that such flowers, chrysanthemums, have been in Western Asia, and are still in Japan, symbols of the sun. 
Plate II.

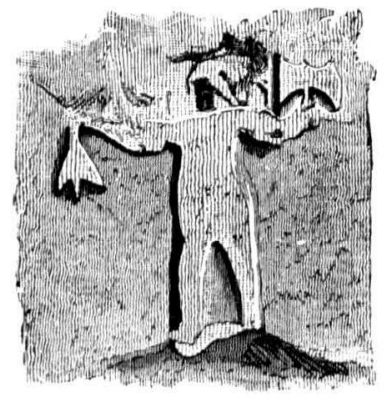

Fig. 6.

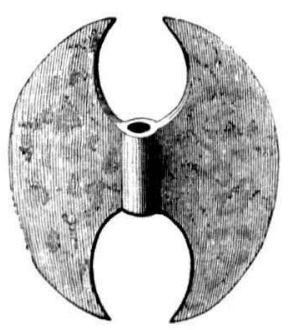

Fig. 8 .

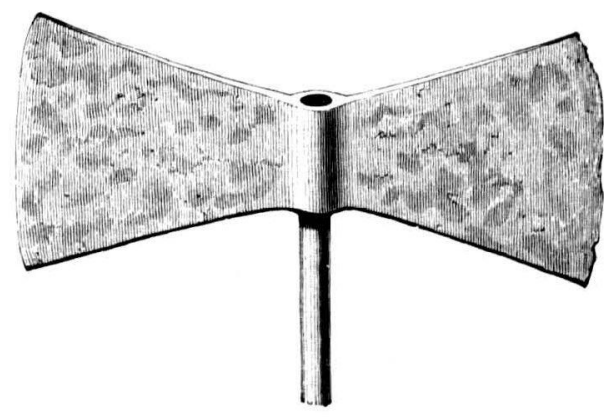

Fig. 7.

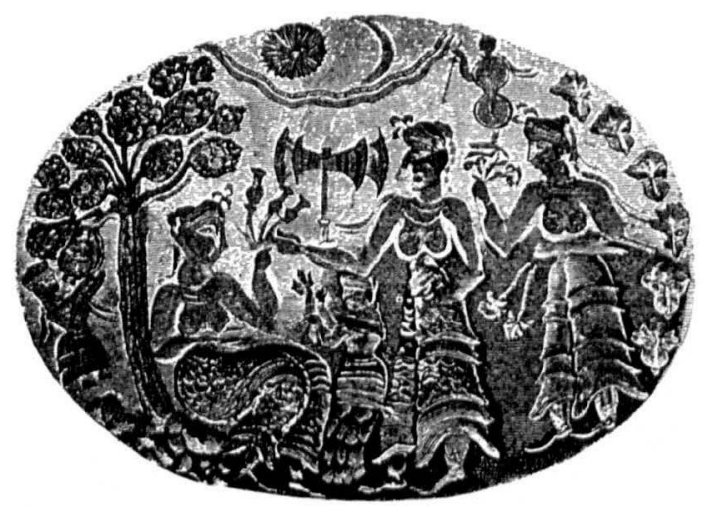

Fig. 10.

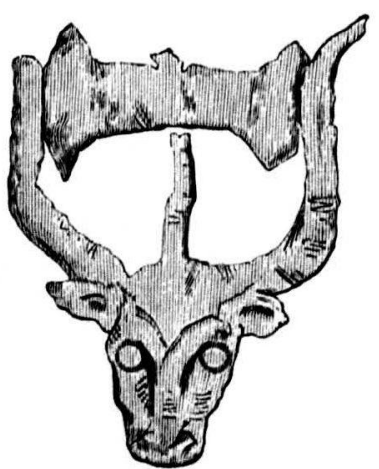

Fig. 9.

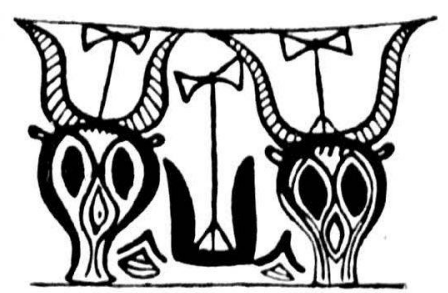

Fig. 11.

THE SUN-GOD'S AXE AND THOR'S HAMMER.

To face $p .64$. 


\section{The Sun-God's Axe and Thor's Hammer. 65}

In one of these Mycenxan tombs an engraved stone was lying, representing several persons grouped round an erect double axe with a handle, in such a way that the scene evidently has a religious significance (Fig. 10).

A double axe, furnished with a handle, is also met with as a symbol or an ornament on Greek pottery, from the latter part of the second millennium B.C. (Fig. II). A similar, sometimes $T$-shaped, figure is also seen on coins from Asia Minor by the side of the standing or sitting Zeus-13aal, and on several Greek coins. Many Greek coins have this sign tripled, as is shown in Fig. 12 , and it has been supposed that when thus arranged it signifies the Trinity that the Greeks, possibly through influences from the Orient, imagrined in connection with Zeus.

Some coins from Elis have the hoad of Zcus on the obverse, and on the reverse side the tripled T-shaped hammer or axe. Other coins from the same place have the head of Zeus on the obverse, and three thunderbolts on the reverse side. This remarkable fact is a further proot that the hammer and the thunderbolt denote the very same thing. It also shows how the Greeks, in the course of time, passed from the older to the younger symbol, from the axe or the hammer to the lightning.

In Greece, as in other countries, the sun god came gradually to be worshipped under many different names.

Though it is believed that Apollo in olden times was figured with a double axe in his hand, yet Zeus carries, in all now existent images from Greece, the lightning, shaped in the well-known manner. Other Greek gods have retained the double axe, or the hammer, of which the outlines correspond to those of the axe. The best known amongst them is Hephaistos, which god, according to the myth, soon after his birth fell down from heaven. There is therefore no doubt about his signifying the lightning. We know that Hephaistos is often depicted with a double axe or a hammer (Fig. 13). An author who has fully treated 
the subject of this god as he appears in the myths and in art says, ${ }^{1}$ - "The heavenly fire, represented by Hephaistos, can originally have been nothing else than the lightning. It was only with the knowledge of metal-work that Hephaistos became a divine smith. The transition is easily explained by the resemblance that imagination readily detects between what occurs in a smithy and during a thunderstorm, especially at a time when the working of metals still seemed something wonderful, requiring the assistance of the gods to be possible. No great stretch of imagination was needed to associate the flashes of lightning with sparks from the forge, and the claps of thunder with the hammer's sounding strokes against the anvil, or to look upon the thunderstorm itself as the work in a heavenly smithy."

Lycurgos also, the Thracian sun god, carried a double axc, and the mallet of Heracles was perhaps originally such a weapon, because Heracles is the oriental sun god who has been transplanted into Greece, and in his own country is usually represented with an axe.

An ancient writer ${ }^{2}$ tells us the names of the four horses that drew the chariot of Apollo. One of these names means lightning, and another thunder. This fact proves that the god of the sun and that of thunder were in Greece, as elsewhere, looked upon as one and the same god. The same conception of the two gods we also find in the legend relating how Apollo with lightning and thunder drove away the Gauls who threatencd Delphi.

The gods of Italy correspond to those of Greece. Vulcanus with his hammer is the same as Hephaistos, and Hercules with his mallet was known also by the

1W. H. Roscher, Ausfuhrliches Lexikon atr griekischen und rimischent Mythologit, vol. i. col. 2047 (Leiprig, t886).

"Hy:rinus, Fab. 183. (Cf. Roscher, of. cit., col. 2006.) "Bronte, quie nos tonitrua appellamus," and "Sterope, qua fulgitrua." Another writer has the names Bronte and Astrape (lightning). (Roscher, of. cit, col. 2007.) 
Plate III.

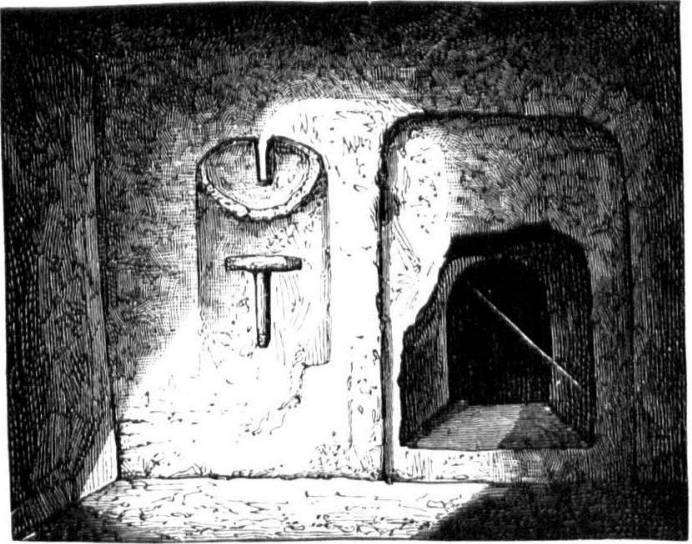

Fig. 15 .

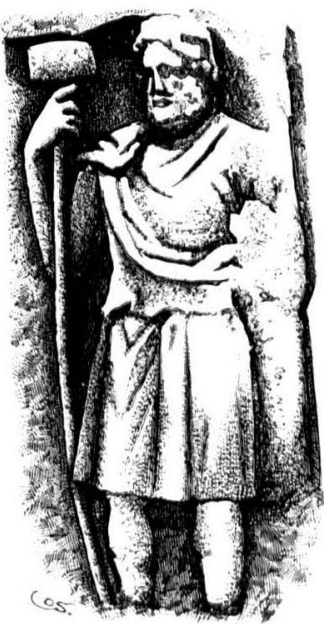

Fig. 16.

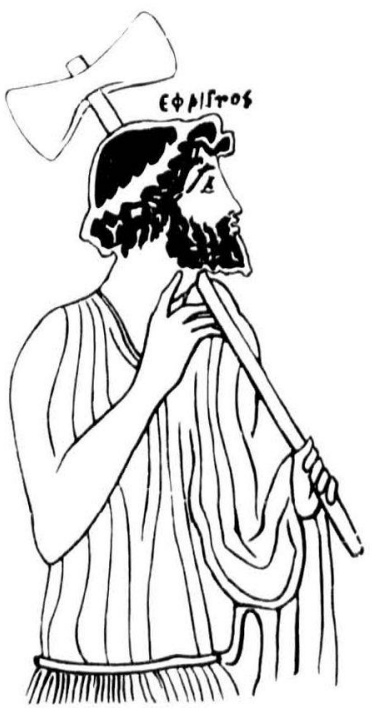

Fig. 13.

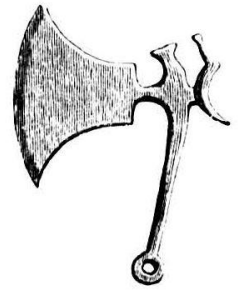

Fig. 14.

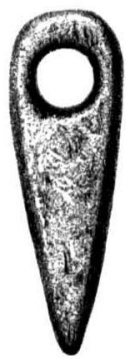

Fig. 18

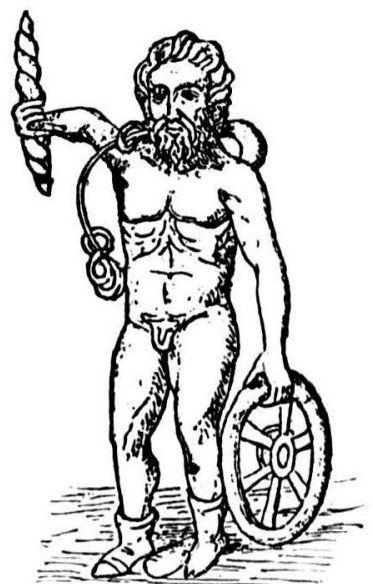

Fig. 17.

THE SUN-GOD'S AXE AND THOR'S HAMMER. 
Romans. In Italy, too, votive and symbolic axes have been met with, dating from very early times (Fig. $14^{3}$ ).

This is cqually the case in Europe north of the Alps. In Gaul we find such symbols as early as the Stone Age. Axes with or without handles are carved on stones forming the walls and roofs of tombs of this period. The image of a man, or rather of a god, with an axe, may be seen on the wall of one of the caves that in Champagne are hewn out of the chalk-rock (Fir. 15), and from the time that Gaul was a Roman province we have many reproductions of a god holding in his hand a hammer with a long handle (Fig. 16). The hammer, symmetrical like the double edged axe, strongly resembics the hammer of the nurthern Thor, but the handle is so long that it reaches the ground. In Latin the name of this Celtic god is Taranis or Tanarus. Whether this name is philologically related to Thunor, the old Teutonic form of Thor's name, is a question with which I cannot deal in this connection. ${ }^{4}$

The Gauls also looked upon the sun god and the god of thunder as onc. This is proved by the images that have been found in Gaul of a god resting with one hand on a wheel, the symbol of the sun, and holding in the other a flash of lightning (Fig. 17).

The Slavonians figured P'erun, the grod of thunder, with a stone axe in his hand. A statue that Prince Wladimir put up in Kiev in the year g8o was made of wood and had a silver head and a grolden beard. In honour of Perun an oak-log fire was kept burning night and day. In Greece, too, the oak was dedicated to the sun grod.

The Ijthuanians worshipped the same god under the name of Perkunas, and the Letts called him Perkons.

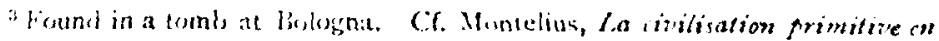
Jalie, vol. i. col. 404, Figh. e. Mlalf size.

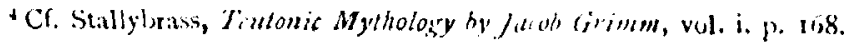




\section{The Sun-God's Axe and Thor's Hammer.}

In Scandinavia, as in Gaul, the axe had a symbolic signification even in the Stone Age. We know this because axes made of amber and dating from this period have several times been found in our countries. Most of the axes are small, and have been worn as ornaments; some have the same shape as the ordinary onc-edged stone axes with an eye for the handle, $(c . g$. Fig. I 8 , from Sweden, full size); others are double-edged and resemble those that occur in the south, (e.r. Fig. I9, from Sweden, half size). But besides these axe-shaped heads of amber, there have been found, both in Sweden and in Denmark, some axes of amber which, being too large for ornaments, must have been used as symbols, (c.g. Fig. 20 , from Sweden, two-thirds size). Judging from what we know previously about such symbols, we may safcly assume that these amber axes, dating from the Stone Age, have been symbols of the sun god.

Flint axes, well polished, have often been found, which are so huge that they probably could not have been used as touls or weapons. Several of these flint axcs have evidently been laid down as offerings. At Ryssvik, in the south of Smaland, fifteen large flint axes were unearthed in 1821 . They were lying in a half circle, with their edges towards the east.

From the Bronze Age some symbolic axes have also survived. At Skorsstorp in Sölermanland two large and magnificent bronze axes were found, adorned with round plates of gold in which pieces of amber are inlaid. Only the surface is of bronze; the interior consists of clay round which the thin bronze has been cast with an extraordinary skill (Fig. 2 I, quarter size). The oak handle is coated with bronze. Two quite similar axes, of thin bronze cast over a still existing clay core, have been found in Denmark.

It is probably not by accident that in both these cases, -as in many other deposits from the Bronze Age as well 
Plate IV.

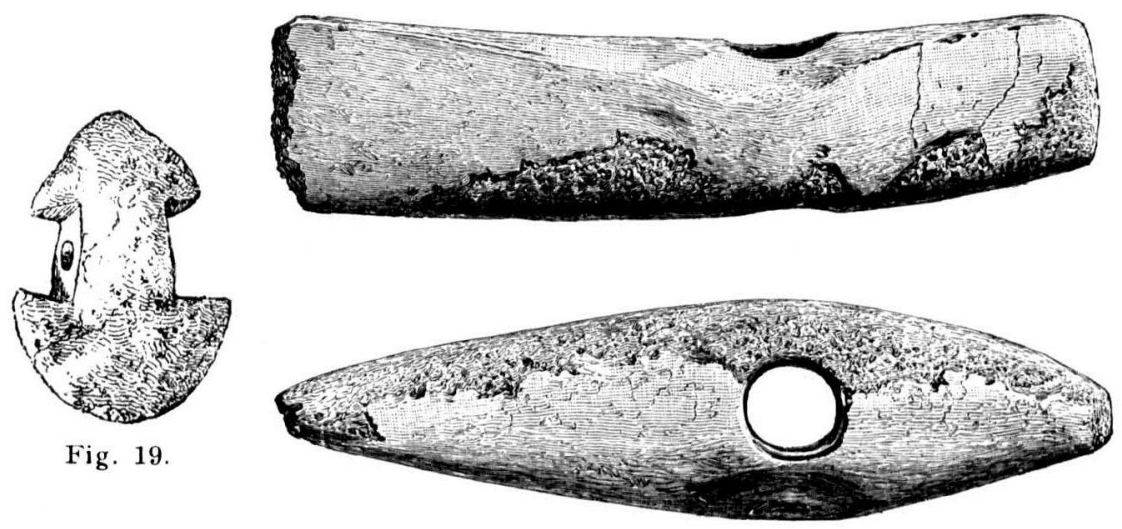

Fig. 20.

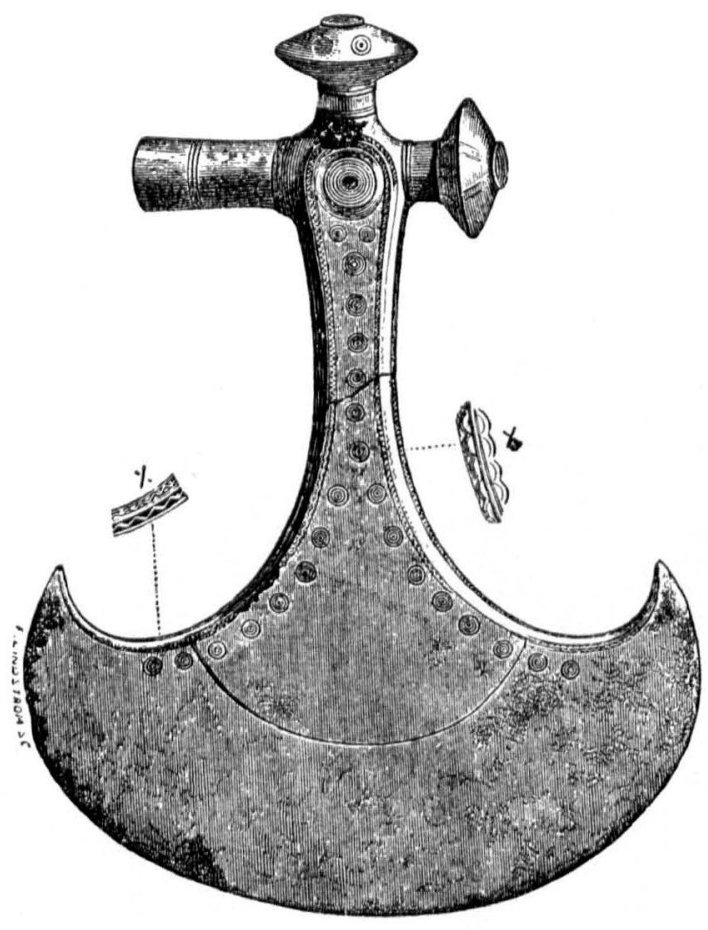

Fig. 21.

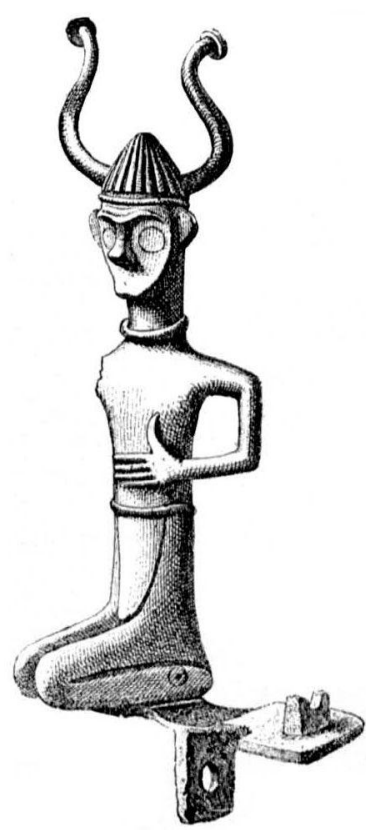

Fig. 22.

THE SUN-GOD'S AXE AND THOR'S HAMMER.

To face p. 68. 
as frrm the Stone Age,-the number of axes discovered wat tare, especially as, on one of the stones forming the wall of the tomb at Kivik on the east coast of Skine, which trmb dates from the first perind of the Bronze Ase, two similarly-shaped axes are figured, one on each side of a cune (Firs. 22). The Scandinavians had already by this time come in some contact with the orientals, anungt whom the cone was one of the symbels of the sun sou. Professor Sven Nilsoson therefore supposed that the conic figure of the Kivik tomb had the same sisnificance. So lons as the furure in the Kivils tomb is the only one of its hime known in the north, we canmet be quite certatu of it: meaning, but the question is of great interest.

Un a reck-carving of the Bronze $\Lambda_{\text {se }}$ at Backa in Behlustion a man is represented axe in hand. He is so much larser than the other persons nerured on the same

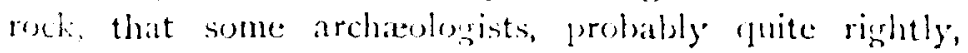
consider him as a supernatural being, the got whose symbul the axe was.

In Denmark a bronze imase, (lige. 23, threc-quarters size has becen found, belonginge to the end of the 13 romse Ase, represonting a man." from the account of the diecevery we know that the imase, when found, carried an axe or a hammer in his right hand, but that hand is now losit.

Tewardis the end of the heathen period we find instead of the axe a symbolical hammer, atike on both sides of the cyce. The fict that in Scandinavia the sun yod's axe became a hammer can be explatined, if we consider the original scandinavian word hamarr. This word hignified oricinally stone: and wats thus a natural term for the weitum of the sun grod or the thunder grod, so leng as this recapon wats thought of as a thunderbolt of stone. later wh, when the word hald acquired its present meaning

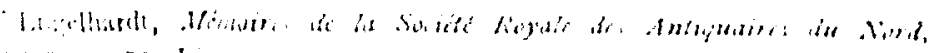
$1572 \therefore 1.71,8$. 


\section{The Sun-God's Axe and Thor's Hammer.}

of hammer, it was just as natural for people to imagine Thor's weapon to be an iron hammer. They represented it then as one of the hammers used in that period.

In old songs Thor's hammer is called Mjollnir; which form the name has in the Icelandic Edda. The word means "the comminuting one," and corresponds to our mjolnare (miller). It refers to the terrible power of the hammcr to crush whatever it encountered.

Of the circumstances under which the hammer was made, legend gives the following account. Loke let some gnomes, the sons of Ivalde, make three valuable presents for Odin, Thor, and Frö (Frey). Then he laid a wager on his own head with a gnome called Brock, that the latter's brother Sindre would not be able to make three equally fine things. Thus provoked, Sindre forged several things, amongst which was Mjollnir, the iron hammer. The gods declared that the hammer was the best of all the gifts, and that Loke had lost the wager. He only saved his head by a quibble that reminds one of "The Merchant of Venice." When the gnome wanted to take his head, Loke answered that the head was certainly his to take, but that to the neck he had no right.

The hammer had only one flaw, the legend goes on, - the handle was too short. The reason for this was that, when Brock was working the bellows while the iron was in the forge, a fly placed itself between his eyes and hurt his eyelids. As the blood then came into his eyes and blinded him, he put up his hand for a moment to rub them. To do this, however, he was obliged to let the bellows stop for a moment, and thus the forging did not succeed so well as Sindre would have liked. The handle was made too short.

Brock gave the hammer to Thor, and told him that he could strike as hard as he liked with it, and whatever he liked, still it would not break. If he threw the hammer, it would never miss the mark and never go too far to 
Plate V.

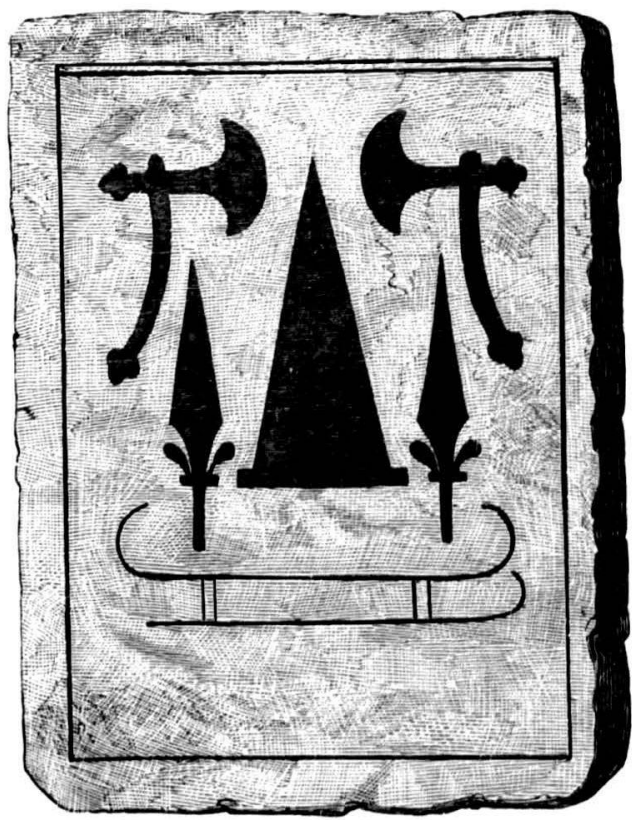

Fig. 22
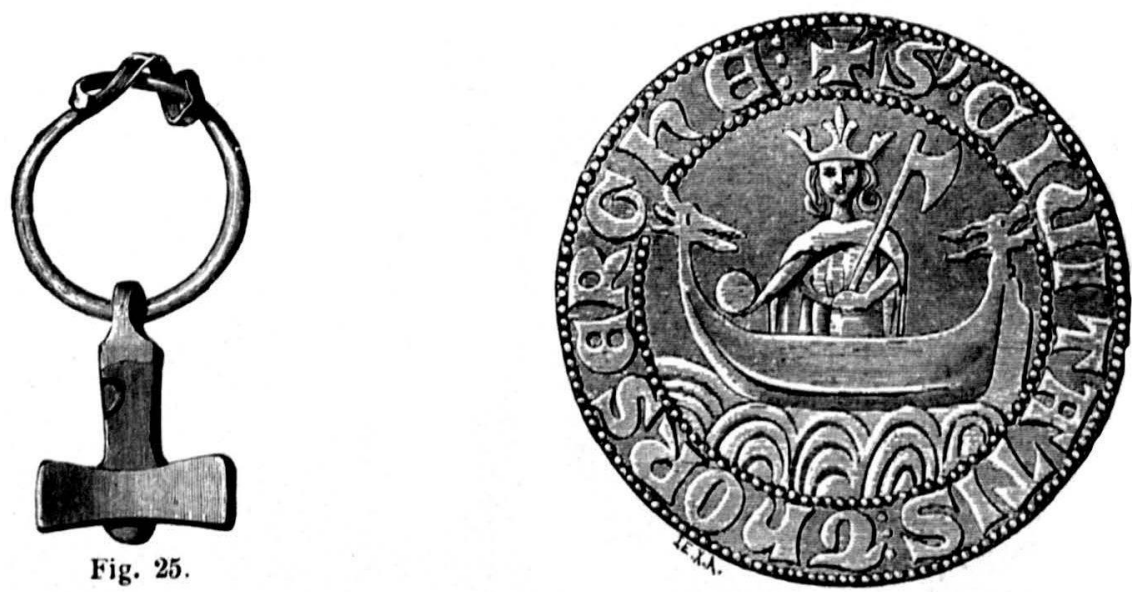

Fig, 29

THE SUN-GOD'S AXE AND THOR'S HAMMER.

To face p. 7o. 
return again to his hand,-i.e. the god of thunder could let one lightning be followed immediately by a new one. If Thor desired it, the hammer would grow so small that he could carry it inside his clothes. It is also mentioned how Thor's hammer "was thrown," and "how it flew through the air." These are most remarkable expressions, reminding us of the fact that the hammer was origrinally identical with the lightning.

In the Icelandic legend of Gylfarinning, Thor is said to passesi three precious things, one of which is the hammer, "that grants and orres know well, when it comes flying through the air. As it has crushed the skulls of many of their fathers and relatives, that they know the hammer is not to be wondered at."

But the hammer was used for many other purposes than as a weapon against giants and ogres.

In the evening Thor used to kill his bucks and cat the flesh. The following morning he got up, scized his hammer, brandished it, and "consecrated" the buckskins on which the bones had been thrown during the meal. In this way the bucks were brought to life again. We remember why one of them is halt.

It was especially at weddings that Thor's hammer must have been of a great importance in heathen times, In Thrym's song, or "The letching of the llammer," it is told how the wedding was celebrated between Thrym, the king of the giants, and Thor, dressed up as lircya. Thrym then says, -

$$
\begin{aligned}
& \text { "Bring the hammer } \\
& \text { the bride wo wed, } \\
& \text { place Mjollnir } \\
& \text { in the maiden's lap." }
\end{aligned}
$$

In this way Thor got again the hammer that had been stolen from him. The first use he made of it was of course to slay Thrym and to mutilate the giant's whole family. 


\section{The Sun-God's Axe and Thor's Hammer.}

The important part that Thor played at weddings is also evident from Herröd's and Bose's saga. Here it is told how Thor's "health" (toast) was drunk at the weddingbanquet before that of any other god. Norwegian folklore also relates Thor's presence at certain weddings.

But consecration by the hammer was not confined to brides. When Balder lay on the pyre, Thor consecrated the pyre with Mjollnir, and on some runic monuments from Scandinavia we read the supplication "May Thor consecrate these runes," or "May Thor hallow these monuments." When there is a hammer figured on a runic stone, it is evident that the monument has been consecrated with the hammer (Fig. $24^{6}$ ). Runic monuments of the Christian era have a cross instead of the hammer.

How our Viking ancestors pictured to themselves the hammer of Thor may be gathered from the aforesaid runic monuments, as well as from many small hammershaped ornaments made of silver or iron which have been dug up (Figs. 25, 26, and 30). Several of these ornaments have been worn on silver chains, just as Christians used to wear small crosses. The difference between the hammer and the cross was not great. To make a cross it was only necessary to continue the handle on the other side of the hammer.

That the likeness between the hammer and the cross was noticed at a comparatively early date is best shown by Snorre's account in the saga of King Hakon, Athelstan's foster son, about the sacrificial festival at Lade, where Jarl Sigurd was present. King Håkon, though baptized in England had to be present at the heathen festival. When the horn was filled for the first "health," Jarl Sigurd dedicated it to Odin. The king received the horn and made the sign of the cross over it. Then one of the peasants asked,- "Why does the king do like that? Is he still unwilling to offer a sacrifice?" Jarl Sigurd answered,-

'Runic stonc at Stenquista, Südermanland, Sweden. 
Plate VI.

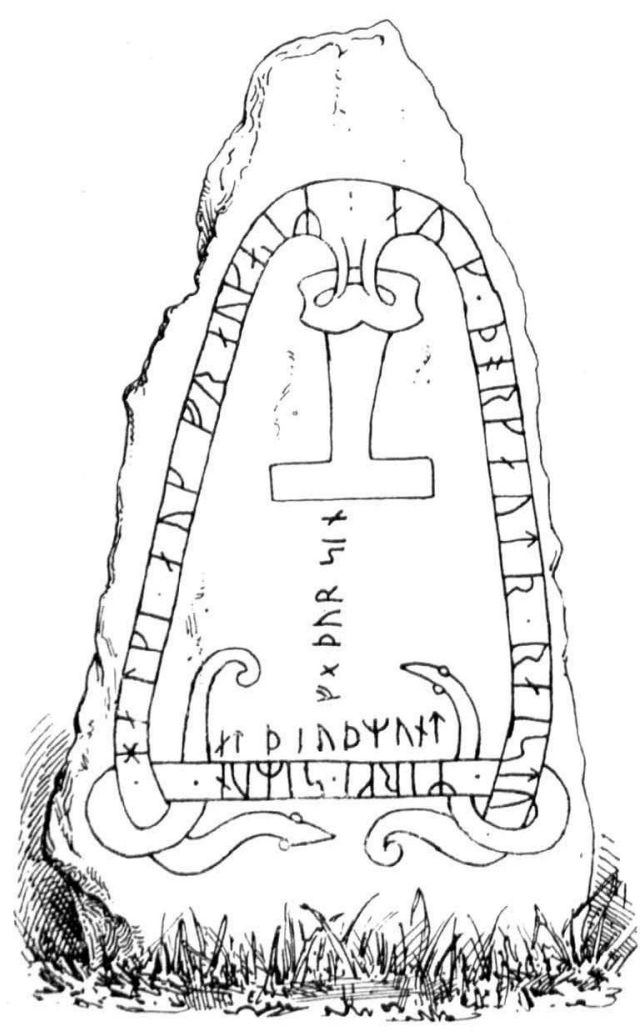

Fig. 24.

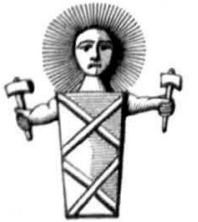

Fig. 27.

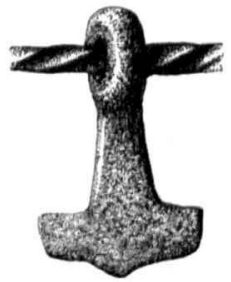

Fig. 30 .

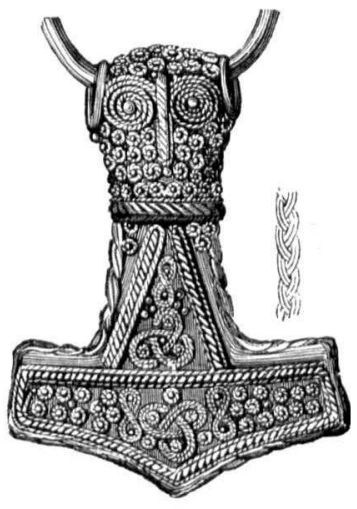

Fig. 26.

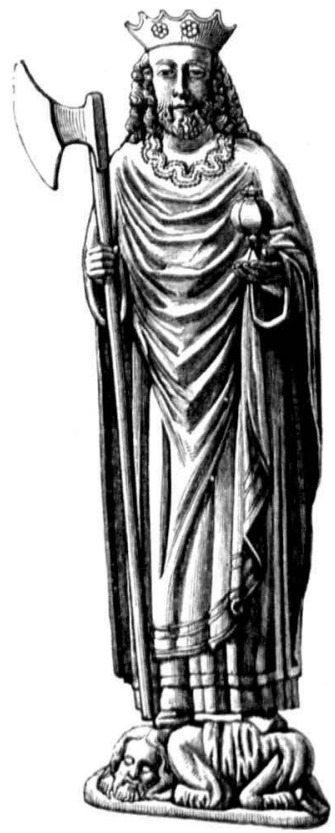

Fig. 28.

THE SUN-GOD'S AXE AND THOR'S HAMMER. 
"The king does like those who believe in their own strength and power, he dedicates the horn to Thor. It was the sign of the hammer that he made before drinking."

The sagas tell us more than once that a wooden statue of Thor with his hammer was to be seen in a temple dedicated to him. For instance, it is mentioned in the saga of Saint Olaf that the king asked the son of that Gudbrand, after whom the large and beautiful "Gudbrandsdal" is named, what the god-image in their temple was like. The answer was,- "It represents Thor. The god is large and hollow, and carries a hammer in his hand. Underneath there is a pedestal on which he stands when he is brought out. There is no lack of grold and silver on him."

Concerning the temple of Old Upsala, Adam of Bremen relates, (towards the end of the eleventh century), that the people there worship three gods. The mightiest of the three, Thor, sits in the middle, and on either side of him sit Odin and Frö, or "Fricco," as he is called by Adam, who is writing in Latin. Like Jupiter, Thor carries a "sceptre." Adam, misunderstanding the description he has received, transforms the hammer to a "sceptrum." Even the two brothers, Johannes and Olaus Magnus, though living some hundred years later than Adam, misunderstood what they had read or heard, and described Thor's image at Old Upsala as carrying a "sceptrum."

Otlier accounts show that Thor was sometimes represented as sitting in his "cart," drawn by bucks.

It is quite evident that the imagres were made of wood. This is also clearly shown by the descriptions we have of god-images that were burnt when Christianity was first introduced.

Several other Thor's hammers are mentioned besides those placed in the hand of his images. Saxo, for instance, tells us about King Magnus Nilsson, who fell in the battle of Fotevik in II34, that, while he was waging war against Sweden, he despoiled a temple of remarkably heavy 


\section{The Sun-God's Axe and Thor's Hammer.}

Thor hammers made of copper or bronze, with which the claps of thunder could be imitated, and which from olden times had been objects of worship,

It is true that Thor is now-a-days thought of merely as the god of thunder, but that he, like other gods of thunder, really was a sun god, we gather partly from the fact that he was called upon, as Adam tells us, when famine was threatening,- - (it belonged to the sun god to grant a good harvest),- -and partly from the peculiarly important part he played at Yule, that great festival of midwinter. The buck, Thor's sacred animal, is still of great significance at Christmastide. Many a Christmas cake, or julkuse, has even now the shape of a buck, and most of us have scen as children the fur-clad jule-buck on Christmas Eve. Formerly it was dressed up in a real buck's head, and in some parts of Scandinavia it carried a wooden hammer (!), whereby its connection with Thor becomes still more obvious.

The worship of Thor was not abolished even when Christianity, after a hard struggle, had finally conquered. Its roots were too deep to be pulled up at once,-indeed, they were so deep that much survives even until this day.

Thor experienced the same fate as many other heathen gods. He lived on partly under his own name, and partly under that of a saint. In saintly attire he moved from his hof (temple) into the Church.

Thor's worship was continued in the Church by that of Saint Olaf, who had the fortune to be slain with an axe at the battle of Sticklastad in 1030. That is why he is figured with an axe in his hand (Fig. 28). The people, who had always been accustomed to worship a god armed with a hammer, recognised in the image of Saint Olaf with the axe the mighty Thor. In another respect, also, the likeness was or became very great. Thor, the sun god, is described as a red-bearded man. Olaf also had, or it was imagined that he had, a red beard, and he was represented with one. Moreover, the images 
of Olaf and the other saints were carved in wood, just as those of the old gods had been.

The fact that the worship of Saint Olaf was not, like that of the Swedish Saint Erik, limited principally to his own country, shows that there must have been some special reason for the prominent position he occupied within the northern Church. Countless images and legends prove that Olaf was commonly worshipped, not only in Norway, but in the other northern countries, - in Finland as well as in Sweden. If the Christian Scandinavians looked upon him in the same way as their heathen ancestors had looked upon Thor, we can easily understand why it was so.

Just as people in old days believed that Thor could grant good harvests, so even in the nineteenth century they have supposed Olaf to be in possession of the same power. Stories from the south of Sweden and from Denmark tell how the peasants were wont to drag the imagre of Saint Olaf round the fields after the sowing. The image of saint Olaf in Vanga church in Vestergötland was carried round in that way, in spite of vigorous protests from the clergy. The peasants had given it the name of the "corn god."

Olaf's axe has, just like Thor's hammer, been used to consecrate with, the word consccrate being here taken in its original meaning of hallowing. We have the most notable example of this use of Olaf's axe in the church close to Simrishamn in Skåne, which is called after him. The saint carries in his hand a silver axe. On Saint Olaf's day, the 29th of July, there is a great muster of people in the church. There they take the axe from the saint's hand, and rub themselves with it nine times. After every third time they replace the axe in the hand of the saint, in order to renew its strength. It is neculess to point out that the numbers three and nine are sacred.

A particularly interesting proof that Olaf is the Christian heir of Thor is given by the following fact. There is a little Swedish town still named after Thor,-Torshalla, in 
old times Torsharg (the sanctuary of Thor). This town ought to have had the image of Thor in its seal, if towns in heathen times had possessed any seals. But there were no seals then; they were not used until the Midile Agres, when it was impossible to put the image of a heathen god in the seal. In its stead we find in the seal of Torshitla the image of Olaf, the saint who had replaced Thor in the popular belief (ligig. 29). The fact that the saint is represented as standing in a boat, which is not elsewhere the case, deserves special attention, because Thor sometimes is figured as standing in a boat, when he is fishing for Midgirdsome.;

Thor has survived the fall both of heathenism and of the Roman Catholic Church in Swcden. Even to the present day many traits are preserved in the language, as well as in popular belief, which show that the ideas formed by our heathen forefathers of this god are still alive, and that he was not conceived of merely as a grod of thunder, but wats also in other ways considered as enjoying the power which belongs to the sun god, especially as regards fertility.

Writing about Wairend, that old part of Smaland where so much of the belief and customs of former ases still remains, Mr. IIyltén-Cavallius says, - " They still look "upon the thunder as a person whom they call alternately. "Ther" or "Thore-Gud," "Gofar," and "Gobonden." He is an old red-bearded man. In 1629 a peasant from Warcnd was summoned for blasphemy against God. He had siid about the rain,-_ "If I had the old man down here I would pull him by the hair on account of this continual rainingr." Thus it is Thor that grives the summer rain, which therefore in Warend is called "Gofar-rain," "Gobonda-rain," or "As-rain." The rumbling of the thunder is produced by 'Thor's driving in his chariot throush the clouds. It is therefore called Thordon after

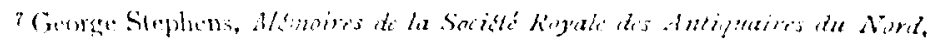
$188.49,11.32$ (Fins).

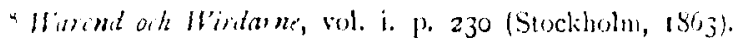


The Sun-God's Axe and Thor's Hammer. 77

him. leople also say that "Gofar is driving," "Gobonden is driving:" "The Thunder is driving." Thor drives not only in the air but also on earth. Then they say that "he is earth-chiving." A peasant met him once, when he wats driving like that. He was sitting "in a small cart drawn by a horse." "Thor has in his hand a bolt of stonce, called Thor's bolt, which is often found in the zrround. Such a Thor's-bolt or Thor's-bolt stone is rend to have in the brose as a protection against every kind of sercery. Thor throw's the bolt after the ogres whose worst enemy he is. $\Lambda$ s soon as the thunder is heard, the ogres hasten to return to their hidingrolaces. That is why so many susts of wind precede a thunderst am."

llyltin-Cavallius erves us also some very remarkable eximples, showing how loner the memory of Thor has been kept up. "Liven tewards the end of the seventeenth centurs," he says,"-. "people in Warend used to swear by Thur-.." Yes, Thore-Gud," "Xo, Thore-(ind." The mont noticcable trace of our commen's older worship of 'Thor is that "Thor's day" (Thurselay) was still in the nineteenth century considered as at sacred day", almest ats a Sunday.

In the Christian Middle Arest Thor's old spriner at Thorsis was called "Saint Thor's Sprine." According to these ideas the god himself became a Roman Catholic: saint, a Saint Thor! Thor has thus, like other beathen forls, lived on alter the victury of Christianity, not only dir.suised as a saint, under a different mane, hut also under his own name, which was then considered as that of a saint. In the same way Santa Venere, the holy Venus, is spoken of in more than one part of ltaly.

The vencration for Thor was so common amomest our forefathers in heathen times that even the lapps came to know him. It was not so longr ago that they worshipled a grod whom they called Thor or some similar name. He slew the oyres. The lapps forured him therefore with a

$$
\text { "(1). a th. } 3.232 .
$$




\section{The Sun-God's Axe and Thor's Hammer.}

hammer in his hand. The hammer they called Thor's hammer, and the rainbow they called Thor's bow, with which he will shoot and slay all ogres that wish to hurt them. They further believed that this Thor had people's health and welfare, life and death, in his power, wherefore they became very frightened when hearing the "Thordön." That is why they sacrificed to him, and put up his image on a sort of primitive altar. The images were made of birch,- the head of the root, and the body of the other part, with a hammer in the hand. Fig. 30 shows such a Lapp image of Thor. ${ }^{10}$

It has of course not been possible here to give an exhaustive account, but the examples I have given will probably suffice to show that the god of the sun and that of thunder were originally one and the same god, that from time out of mind and by widely different peoples the axe has been considered as the sun-god's weapon, and that amongst certain peoples it became a hammer. The idea of Thor's hammer is therefore not peculiar to the Scandinavians.

In order to get a correct result in this, as in every other similar enquiry, it is necessary to look far afield. By doing that we get a view of the connection between different peoples and different periods which we could never get in any other way.

It is certainly dangerous to deal with mythological questions, because we are too easily tempted to leave the terra firma of scientific investigation and to sink down into the marshy ground of hypothesis. But the danger is not so great if, as in the present enquiry, we endeavour to keep aloof from explanations on which opinions may differ, and confine ourselves chiefly to the putting down of facts.

Oscar Montelius.

${ }^{10}$ Gustaf von Düben, Om Lappland och Lapparne, p. 288, Fig. 72, (Stockholm, 1873). 